\title{
Structures of tantalum pentoxide thin films formed by reactive sputtering of Ta metal
}

\author{
Peng-Heng Chang ${ }^{\mathrm{a}}$, Hung-Yu Liu ${ }^{\mathrm{b}}$ \\ ${ }^{a}$ Institute of Materials Science and Engineering, National Chiao Tung University, Sinchu, Taiwan \\ ${ }^{\mathrm{b}}$ Materials Science Laboratory, PO Box 655936, Mail Station 147, Texas Instruments Inc., Dallas, TX 75265, USA
}

Received 31 March 1994; accepted 11 October 1994

\begin{abstract}
Reactively sputtered $\mathrm{Ta}_{2} \mathrm{O}_{5}$ films adhere poorly on bare $\mathrm{Si}$ substrate, but the adhesion improves dramatically on a thermally oxidized Si surface. The films are non-stoichiometric and the atomic ratio of $\mathrm{O}$ to $\mathrm{Ta}$ is typically higher than 2.5 but decreases with increasing annealing temperature. The variation in non-stoichiometry is also reflected by a small decrease in lattice constants with increasing annealing temperature as revealed by X-ray diffraction. About 2 at. $\%$ of residual $\mathrm{Ar}$ is detected in $\mathrm{Ta}_{2} \mathrm{O}_{5}$ film formed by $70 \% \mathrm{Ar}-30 \% \mathrm{O}_{2}$ sputtering. The as-deposited $\mathrm{Ta}_{2} \mathrm{O}_{5}$ film is amorphous and it transforms to crystalline $\mathrm{Ta}_{2} \mathrm{O}_{5}$ at temperatures higher than $600^{\circ} \mathrm{C}$. Crystalline $\mathrm{Ta}_{2} \mathrm{O}_{5}$ films contain numerous amorphous particles which have been previously incorrectly identified as voids. They are probably the remnants of the uncrystallized amorphous $\operatorname{Ta}_{2} \mathrm{O}_{5}$ materials. The amorphous particles have a bimodal size distribution and the average size increases with increasing annealing temperature. The deterioration of dielectric properties in crystallized $\mathrm{Ta}_{2} \mathrm{O}_{5}$ films is unlikely to arise from these amorphous particles because amorphous $\mathrm{Ta}_{2} \mathrm{O}_{5}$ is known to have very low leakage current. An interfacial $\mathrm{SiO}_{2}$ layer forms at the $\mathrm{Ta}_{2} \mathrm{O}_{5}-\mathrm{Si}$ interface during reactive sputtering and its thickness increases with increasing oxygen content in the sputtering gas. Annealing at high temperature in $\mathrm{Ar}$ ambient has little effect on the thickness of this interfacial $\mathrm{SiO}_{2}$ layer.
\end{abstract}

Keywords: Dielectrics; Oxides; Structural properties; Tantalum

\section{Introduction}

Tantalum oxide films are of interest for applications in high temperature resistance [1], anti-reflection coatings for solar cells [2], optical waveguides [3], oxygen sensors [4], and capacitor diclcetric materials [5]. In recent years they have received increasing attention as an alternative dielectric to replace thin $\mathrm{SiO}_{2}$ films for storage capacitors in very large-scale-integrated memory cells and as gate insulators in metal-oxide-semiconductor devices $[6,7]$. Tantalum oxide films can be formed by at least five different methods: (1) thermal oxidation of sputtered tantalum films [4, 8-10]; (2) chemical vapor deposition (CVD) using a $\mathrm{TaCl}_{5}$ [11], $\mathrm{Ta}\left(\mathrm{OC}_{2} \mathrm{H}_{5}\right)_{5}$ [12] or $\mathrm{TaCl}_{2}\left(\mathrm{OC}_{2} \mathrm{H}_{5}\right)_{2} \mathrm{C}_{5} \mathrm{H}_{7} \mathrm{O}_{2}$ [13] source; (3) anodization of Ta metal films [14-16]; (4) magnetron sputter deposition from a $\mathrm{Ta}_{2} \mathrm{O}_{5}$ target using reactive $\mathrm{O}_{2}-\operatorname{Ar}$ gas [17]; and (5) reactive sputtering of a pure Ta target using $\mathrm{O}_{2}-\mathrm{Ar}$ gas $[18,19]$.

$\mathrm{Ta}_{2} \mathrm{O}_{5}$ film formed by thermal oxidation of Ta metal is usually amorphous if oxidized below $600{ }^{\circ} \mathrm{C}$, but it crystallizes with deteriorating electrical properties (higher leakeage current and lower breakdown voltage) when annealed in inert or oxidizing ambients [20, 21]. The crystallization process is apparently thermally activated for it requires $14 \mathrm{~h}$ at $600{ }^{\circ} \mathrm{C}$ but less than $30 \mathrm{~min}$ at $900{ }^{\circ} \mathrm{C}$ [20]. Thermal oxidation of $\mathrm{Ta}$ metal deposited on an $\mathrm{Si}$ substrate not only produces $\mathrm{aTa}_{2} \mathrm{O}_{5}$ film but also an interfacial $\mathrm{SiO}_{2}$ layer is formed at the $\mathrm{Ta}_{2} \mathrm{O}_{5}-\mathrm{Si}$ interface [21]. A similar interfacial $\mathrm{SiO}_{2}$ layer is also observed when $\mathrm{Ta}_{2} \mathrm{O}_{5}$ is formed by reactive sputtering of a Ta target [22]. In the latter case, the $\mathrm{Ta}_{2} \mathrm{O}_{5}$ film is always amorphous in the as-deposited condition but crystallizes upon annealing at tempera- 
tures in excess of $600{ }^{\circ} \mathrm{C}$ [23]. Like thermal oxide, the reactively sputtered tantalum oxide also exhibits inferior electrical properties in crystalline form [24].

Anodic tantalum oxide is also amorphous in general, but prolonged anodization at constant voltage will cause crystalline $\mathrm{Ta}_{2} \mathrm{O}_{5}$ to grow at the oxide- $\mathrm{Ta}$ interface [25-27]. The crystalline anodic $\mathrm{Ta}_{2} \mathrm{O}_{5}$ is not produced by the crystallization of existing amorphous $\mathrm{Ta}_{2} \mathrm{O}_{5}$ but is a new oxide growing at the interface between the $\mathrm{Ta}$ substrate and the amorphous $\mathrm{Ta}_{2} \mathrm{O}_{5}$ layer and it physically displaces and spalls the overlaying amorphous oxide [27]. The amorphous anodic tantulum oxide can be crystallized by thermal treatment at temperatures higher than $500{ }^{\circ} \mathrm{C}$ [28]. $\mathrm{CVD} \mathrm{Ta}_{2} \mathrm{O}_{5}$ has the advantage of better step coverage compared with other types of $\mathrm{Ta}_{2} \mathrm{O}_{5}$ film, but it shows poor d.c. conduction behavior (i.e. much higher leakage current) $[12,13,29]$. CVD $\mathrm{Ta}_{2} \mathrm{O}_{5}$ films formed at low temperatures $\left(<500^{\circ} \mathrm{C}\right)$ tend to be amorphous $[13,30]$ while those formed at higher temperatures are crystalline [30, 31]. Recently it was found that the leakage current of CVD $\mathrm{Ta}_{2} \mathrm{O}_{5}$ can be greatly reduced by a two-step anneal using ozone and dry $\mathrm{O}_{2}$ [12].

In this paper the structure of $\mathrm{Ta}_{2} \mathrm{O}_{5}$ films formed by reactive sputtering of a Ta target is studied. Several advanced characterization techniques, such as thin film X-ray diffraction, Rutherford backscattering spectrometry (RBS) and high resolution transmission electron microscopy (HRTEM), are employed synergistically to provide a comprehensive picture of the structural evolution of the oxide films during rapid thermal annealing.

\section{Experimental procedurc}

Tantalum pentoxide films were formed by d.c. magentron sputtering of a pure $\mathrm{Ta}$ target using reactive $\mathrm{O}_{2}-\mathrm{Ar}$ gas. The substrates were $100 \mathrm{~mm}$ in diameter, p-type, $\operatorname{Si}\{111\}$ wafers with or without a thermally grown $\mathrm{SiO}_{2}$ layer. Table 1 summarizes the substrates and sputtering gas compositions for the four groups of wafers studied. To facilitate the following discussions they are designated as $\mathrm{A}, \mathrm{B}, \mathrm{C}$ and $\mathrm{D}$ series. The nominal thickness of $\mathrm{Ta}_{2} \mathrm{O}_{5}$ film was $100 \mathrm{~nm}$, constant across the series. The nominal thickness of the ther-

Table 1

Substrates and sputtcring gas composition

\begin{tabular}{lll}
\hline Series & Substrate & Gas composition \\
\hline $\mathrm{A}$ & $\mathrm{Si}$ & $70 \% \mathrm{Ar}-30 \% \mathrm{O}_{2}$ \\
$\mathrm{C}$ & $\mathrm{Si}$ & $100 \% \mathrm{O}_{2}$ \\
$\mathrm{C}$ & $\mathrm{SiO}_{2} / \mathrm{Si}$ & $70 \% \mathrm{Ar}-30 \% \mathrm{O}_{2}$ \\
$\mathrm{D}$ & $\mathrm{SiO}_{2} / \mathrm{Si}$ & $100 \% \mathrm{O}_{2}$ \\
\hline
\end{tabular}

mally grown $\mathrm{SiO}_{2}$ layer was $35 \mathrm{~nm}$ in the $\mathrm{C}$ and $\mathrm{D}$ series. The films were subsequently rapidly thermally annealed for $10 \mathrm{~s}$ in an $\mathrm{Ar}$ ambient at 600,800 or $1000^{\circ} \mathrm{C}$, using separate wafers for each temperature. The structures of the as-deposited and the annealed wafers were examined by thin film X-ray diffraction, transmission electron microscopy (TEM), and RBS. The detailed procedures of these analyses were similar to those reported previously [32].

\section{Results and discussion}

The X-ray diffraction patterns obtained from the four series are similar for the same annealing conditions, irrespective of the differences in substrate and sputtering gas composition. For the sake of brevity, we will only demonstrate the results for the D series at three different annealing temperatures, as shown in Fig. 1. The pattern for the as-quenched sample is not shown because it is practically the same as for the sample annealed at $600^{\circ} \mathrm{C}$. It is clear from Fig. 1 that $\mathrm{Ta}_{2} \mathrm{O}_{5}$ film is amorphous below $600{ }^{\circ} \mathrm{C}$ as implied by the broad diffuse-scattering background of the $600{ }^{\circ} \mathrm{C}$ spectrum. Annealing at 800 or $1000^{\circ} \mathrm{C}$ results in the crystallization of the films as revealed by the appearance of diffraction peaks in the 800 and $1000^{\circ} \mathrm{C}$ spectra. All the peaks shown in Fig. 1 can be ascribed to the orthorhombic $\mathrm{Ta}_{2} \mathrm{O}_{5}$ phase with lattice constants $a=0.6198 \mathrm{~nm}, b=4.029 \mathrm{~nm}$ and $c=0.3888 \mathrm{~nm} \mathrm{[33].}$ The reflecting lattice plane(s) corresponding to the peaks are also labeled in Fig. 1. Close examination of the 800 and $1000{ }^{\circ} \mathrm{C}$ spectra in Fig. 1 reveals a small shift of peak positions toward lower $2 \theta$ angle. This implies a decrease of lattice constants for the crystalline $\mathrm{Ta}_{2} \mathrm{O}_{5}$ films as the annealing temperature is increased. This variation of lattice constants is probably due to the change in non-stoichiometry of the films upon annealing.

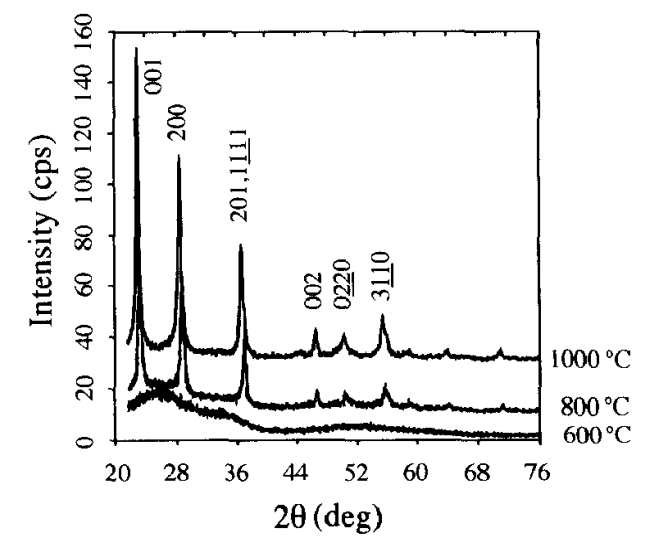

Fig. 1. Thin film X-ray diffraction patterns of $\mathrm{Ta}_{2} \mathrm{O}_{5}$ films annealed at three different temperatures. The films were sputtered on $\mathrm{Si}$ substrates using pure oxygen gas. 

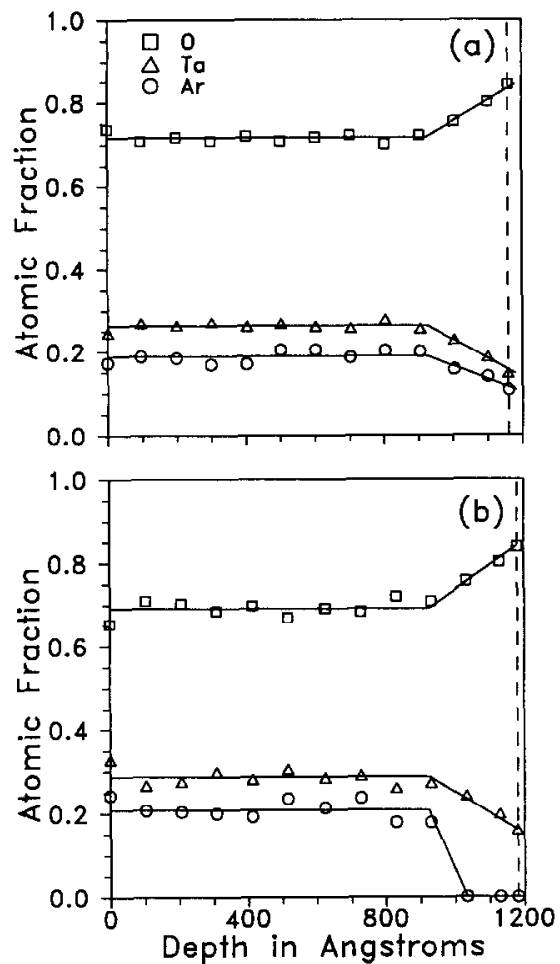

Fig. 2. RBS depth profile of a $\mathrm{Ta}_{2} \mathrm{O}_{5}$ film formed by $\mathrm{Ar}-\mathrm{O}_{2}$ sputtering on an $\mathrm{SiO}_{2}$ substrate and annealed at (a) $600^{\circ} \mathrm{C}$ and (b) $1000^{\circ} \mathrm{C}$. The atomic fraction scale for $\mathrm{Ar}$ is expanded by a factor of 10 .

The stoichiometry of the films can be determined by RBS depth profiling. Because of the poor film quality in the A and B series, RBS depth profiling was performed
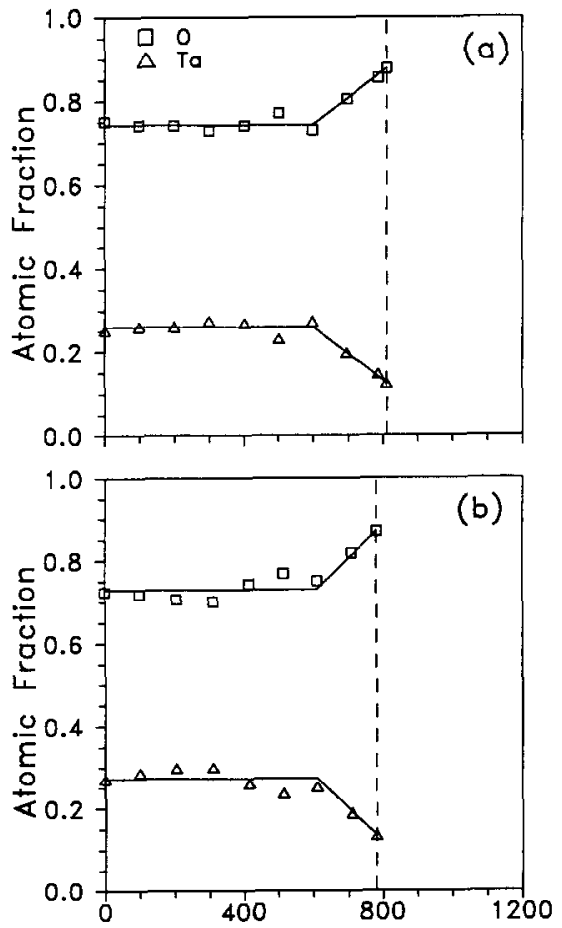

Fig. 3. RBS depth profile of a $\mathrm{Ta}_{2} \mathrm{O}_{5}$ film formed by pure $\mathrm{O}_{2}$ sputtering on an $\mathrm{SiO}_{2}$ substrate and annealed at (a) $600^{\circ} \mathrm{C}$ and (b) $1000{ }^{\circ} \mathrm{C}$ only on the $C$ and D series. Fig. 2 and Fig. 3 show the concentration profiles of samples annealed at 600 and $1000{ }^{\circ} \mathrm{C}$ for the $\mathrm{C}$ and $\mathrm{D}$ series respectively. The vertical broken line in each figure represents the $\mathrm{Ta}_{2} \mathrm{O}_{5}-\mathrm{SiO}_{2}$ interface as determined by TEM. It is evident that films formed by $\mathrm{Ar}-\mathrm{O}_{2}$ sputtering (Fig. 2) contain about 2 at.\%Ar, which is not present in films sputtered by pure $\mathrm{O}_{2}$ (Fig. 3). The Ar concentration in Fig. 2 remains at about 2 at. $\%$ independent of annealing temperature, which is not unexpected in view of the short annealing time (only $10 \mathrm{~s}$ ). The concentration of Ta and oxygen is fairly constant throughout the $\mathrm{Ta}_{2} \mathrm{O}_{5}$ film in each case, except near the $\mathrm{Ta}_{2} \mathrm{O}_{5}-\mathrm{SiO}_{2}$ interface. Using the concentrations in the bulk of the film for calculation, the $\mathrm{O} / \mathrm{Ta}$ ratio is found to be 2.71 and 2.85 at $600{ }^{\circ} \mathrm{C}$ for the $\mathrm{C}$ and $\mathrm{D}$ series respectively. This ratio is decreased to 2.65 and 2.68 at $1000{ }^{\circ} \mathrm{C}$ for the $\mathrm{C}$ and $\mathrm{D}$ series respectively. The change in the lattice constants of the films as revealed by the X-ray results discussed previously is very likely related to this variation in non-stoichiometry.

The cross-sectional TEM microstructures of the $\mathrm{Ta}_{2} \mathrm{O}_{5}$ films formed on bare $\mathrm{Si}$ substrates ( $\mathrm{A}$ and $\mathrm{B}$ series) and annealed at different temperatures are shown in Fig. 4 and Fig. 5 respectively. Several observations can be made from these figures, as follows.

(1) Although the original substrate is a bare $\mathrm{Si}$ wafer, a thin layer of $\mathrm{SiO}_{2}$ is formed at the $\mathrm{Ta}_{2} \mathrm{O}_{5}-\mathrm{Si}$ interface as a result of the reactive sputtering. The thickness of the $\mathrm{SiO}_{2}$ layer changes little with increasing annealing temperature, indicating that it is formed during the sputtering. This result is in agreement with that of others [9] who had shown that oxygen would diffuse through $\mathrm{Ta}_{2} \mathrm{O}_{5}$ film during reactive sputtering to oxidize the underlying $\mathrm{Si}$ substrate. The $\mathrm{SiO}_{2}$ thickness increases with increasing $\mathrm{O}_{2}$ content in the sputtering gas, being $8 \mathrm{~nm}$ for the $\mathrm{Ar}-30 \% \mathrm{O}_{2}$ gas and $18 \mathrm{~nm}$ for the pure $\mathrm{O}_{2}$ case.

(2) The adhesion of the films to Si is poor. Delamination is observed even in the as-deposited condition. Annealing the films at higher temperature worsens adhesion. Films formed by pure $\mathrm{O}_{2}$ sputtering are worse than those formed by $\mathrm{Ar}-\mathrm{O}_{2}$ sputtering. Note that delamination is not at the $\mathrm{Ta}_{2} \mathrm{O}_{5}-\mathrm{SiO}_{2}$ interface, but is inside the $\mathrm{Ta}_{2} \mathrm{O}_{5}$ film about $10 \mathrm{~nm}$ away from the interface.

(3) Consistent with the X-ray results, the as-deposited films and films annealed at $600{ }^{\circ} \mathrm{C}$ are amorphous. Films annealed at 800 and $1000^{\circ} \mathrm{C}$ showed evidence of crystallinity.

(4) Pore-like features are formed in the crystalline $\mathrm{Ta}_{2} \mathrm{O}_{5}$ film. They are discernible in the samples annealed at $800^{\circ} \mathrm{C}$ and become evident in the sample annealed at $1000^{\circ} \mathrm{C}$.

The films formed on oxidized Si wafers and annealed at different temperatures are shown in Fig. 6 and Fig. 7 


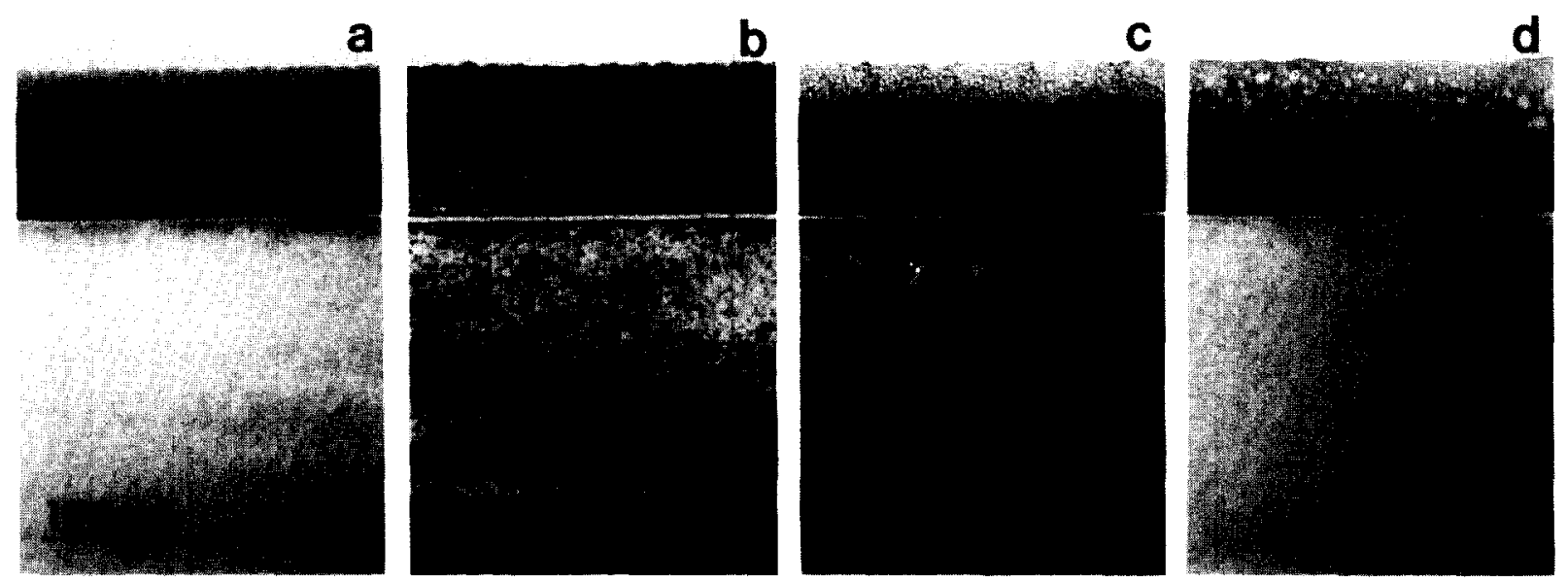

Fig. 4. Cross-sectional TEM microstructure of $\mathrm{Ta}_{2} \mathrm{O}_{5}$ films formed on Si substrates by $\mathrm{Ar}-\mathrm{O}_{2}$ sputtering: (a) as-deposited film; (b) -(d) films rapidly thermally annealed for $10 \mathrm{~s}$ at (b) $600^{\circ} \mathrm{C}$, (c) $800^{\circ} \mathrm{C}$ and (d) $1000^{\circ} \mathrm{C}$.
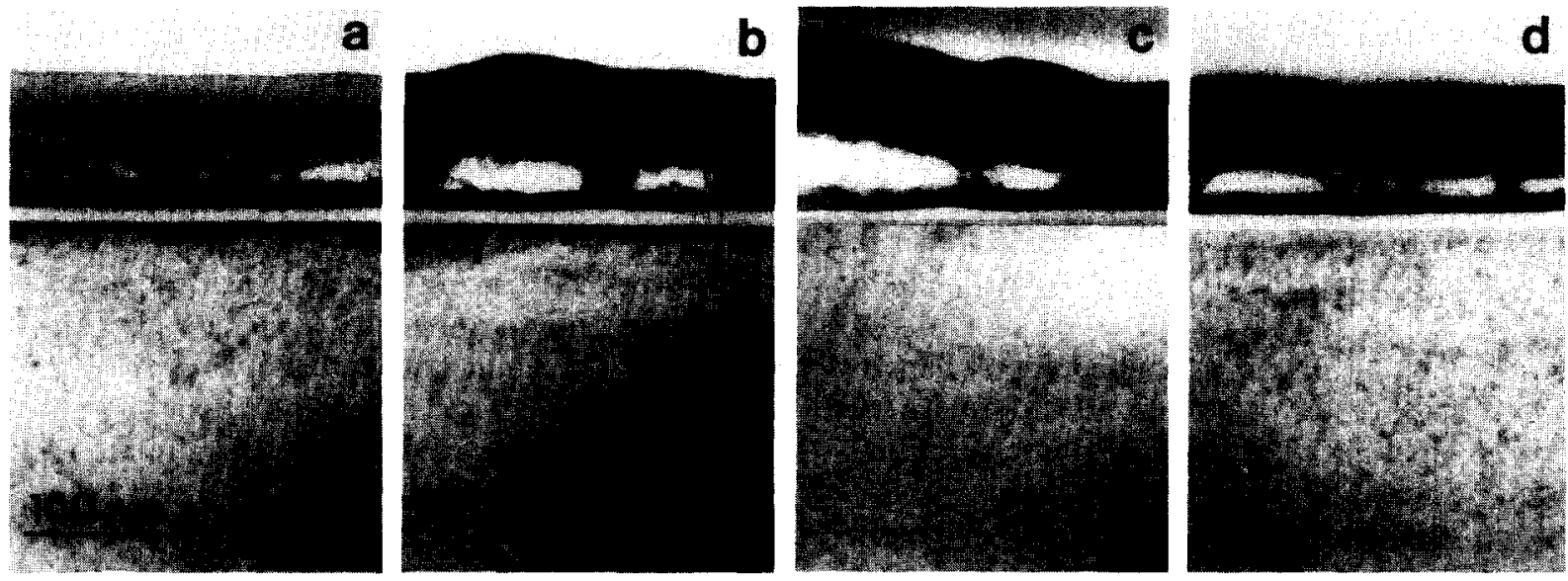

Fig. 5. Cross-sectional TEM microstructure of $\mathrm{Ta}_{2} \mathrm{O}_{5}$ films formed on Si substrates by pure $\mathrm{O}_{2}$ sputtering: (a) as-deposited film; (b)-(d) films rapidly thermally annealed for $10 \mathrm{~s}$ at (b) $600{ }^{\circ} \mathrm{C}$, (c) $800^{\circ} \mathrm{C}$ and (d) $1000^{\circ} \mathrm{C}$.
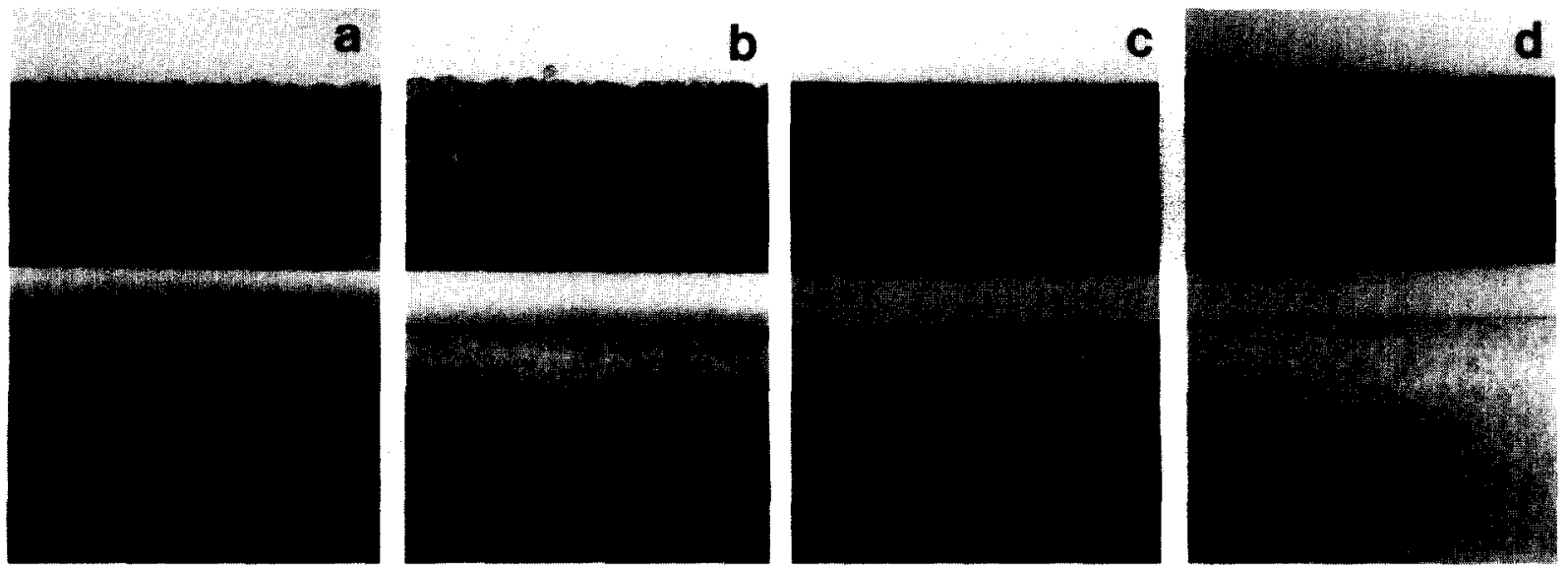

Fig. 6. Cross-sectional TEM microstructure of $\mathrm{Ta}_{2} \mathrm{O}_{5}$ films formed on $\mathrm{SiO}_{2}$ substrates by $\mathrm{Ar}-\mathrm{O}_{2}$ sputtering: (a) as-deposited film; (b)-(d) films rapdily thermally annealed for $10 \mathrm{~s}$ at (b) $600{ }^{\circ} \mathrm{C}$, (c) $800^{\circ} \mathrm{C}$ and (d) $1000^{\circ} \mathrm{C}$. 

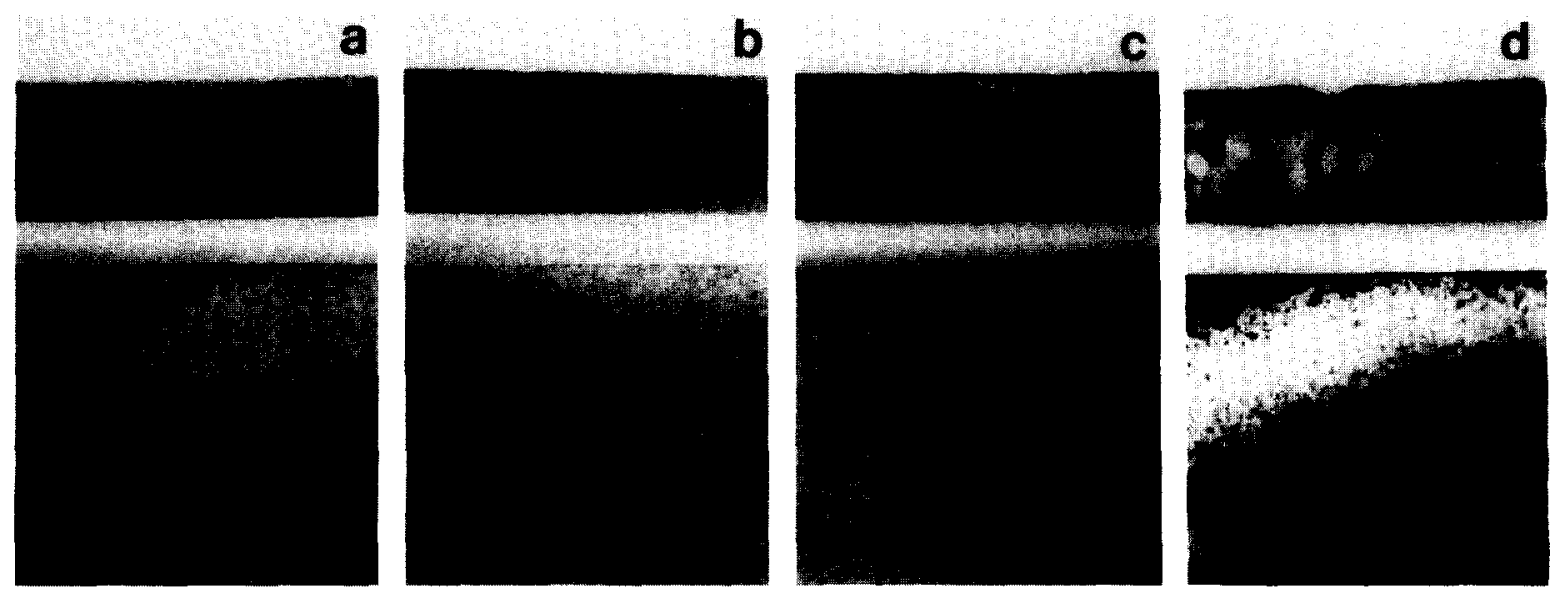

Fig. 7. Cross-sectional TEM microstructure of $\mathrm{Ta}_{2} \mathrm{O}_{5}$ films formed on $\mathrm{SiO}_{2}$ substrates by pure $\mathrm{O}_{2}$ sputtering: (a) as-deposited film; (b) - (d) films rapidly thermally annealed for $10 \mathrm{~s}$ at (b) $600{ }^{\circ} \mathrm{C}$, (c) $800{ }^{\circ} \mathrm{C}$ and (d) $1000^{\circ} \mathrm{C}$.

for $\mathrm{Ar}-\mathrm{O}_{2}\left(\mathrm{C}\right.$ series) and purc $\mathrm{O}_{2}$ (D series) sputtering respectively. Comparing these two figures with Figs. 4 and 5 , it is apparent that the presence of thermal oxide on the substrate improves the adhesion of the $\mathrm{Ta}_{2} \mathrm{O}_{5}$ films dramatically. Delamination is not observed in any of the micrographs shown in Figs. 6 and 7 and the film quality is excellent. Pore-like features are also present and they seem to appear at lower temperature in the pure $\mathrm{O}_{2}$ sputtered films than in the $\left(\mathrm{Ar}-\mathrm{O}_{2}\right)$-sputtered films.

Close examination of the crystalline $\mathrm{Ta}_{2} \mathrm{O}_{5}$ films by HRTEM reveals that the pore-like features are not voids. Fig. 8 shows a typical high resolution transmission electron micrograph of the structurc within a $\mathrm{Ta}_{2} \mathrm{O}_{5}$ grain and the pore-like features are unequivocally amorphous in nature. In the conventional transmission electron micrographs shown in Figs. 4-7 many of these features appear to be faceted, but in HRTEM the faceting is less obvious. Numerous amorphous par-

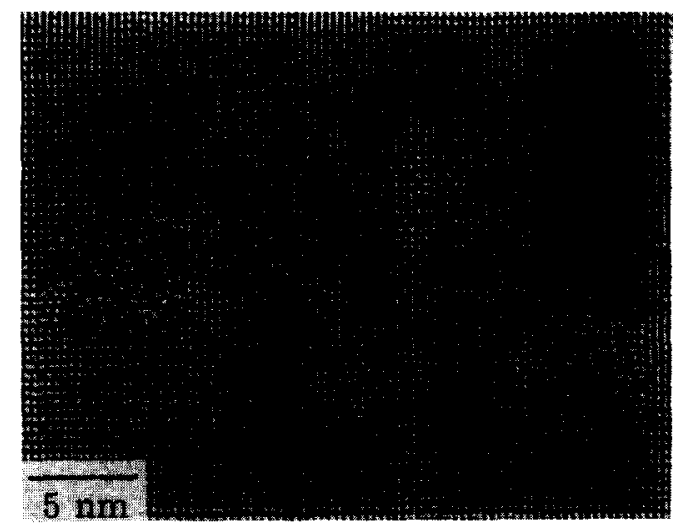

Fig. 8. Planar high resolution transmission electron micrograph showing the structure of crystalline $\mathrm{Ta}_{2} \mathrm{O}_{5}$ film within a grain. The film was formed by $\mathrm{Ar}-\mathrm{O}_{2}$ sputtering on an $\mathrm{SiO}_{2}$ substrate and subsequently annealed at $1000^{\circ} \mathrm{C}$. ticles are also located at grain boundaries, and a typical example is shown in Fig. 9 (the edges of the amorphous particles sometimes exhibit lattice fringes due to the overlapping of crystalline materials over amorphous regions). The grain boundary particles extend into grains on both sides of the boundary and are much larger in size than those located in the grain interior. The bimodal size distribution of the amorphous particles is best revealed in Fig. 10 which shows plane view transmission electron micrographs of a film annealed at $1000^{\circ} \mathrm{C}$. The grain boundaries in Fig. 10(a) are decorated with many large irregular-shaped amorphous particles while smaller particles in the grain interior can be casily identified in Fig. 10(b).

Pore-like features have been previously observed by others in $\mathrm{Ta}_{2} \mathrm{O}_{5}$ films formed by r.f. magnetron sputtering of a pure $\mathrm{Ta}$ target using $\mathrm{Ar}-\mathrm{O}_{2}$ gas $[23,24]$. We

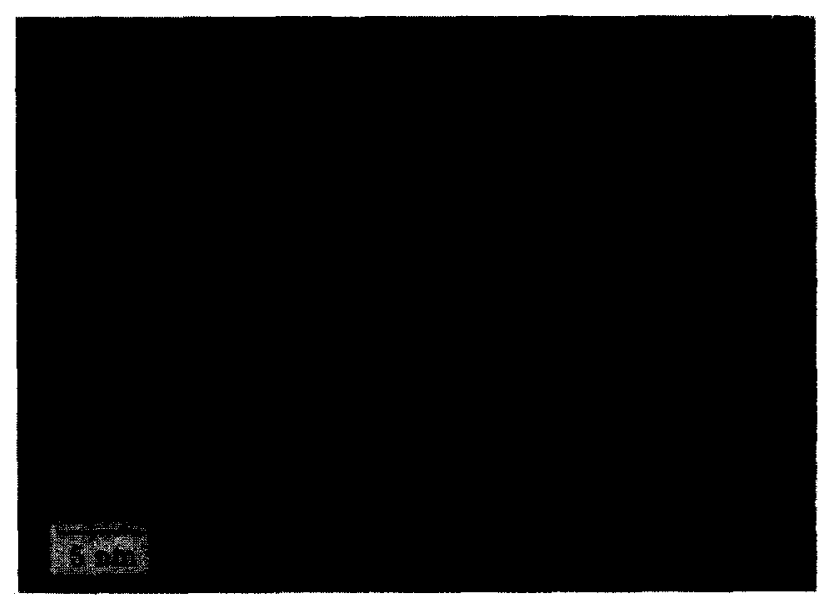

Fig. 9. Planar high resolution transmission electron micrograph showing the structure of crystalline $\mathrm{Ta}_{2} \mathrm{O}_{5}$ film at grain boundaries. (The grain boundaries are marked by pairs of triangles). The film was formed by $\mathrm{Ar}-\mathrm{O}_{2}$ sputtering on an $\mathrm{SiO}_{2}$ substrate and subsequently annealed at $1000^{\circ} \mathrm{C}$. 


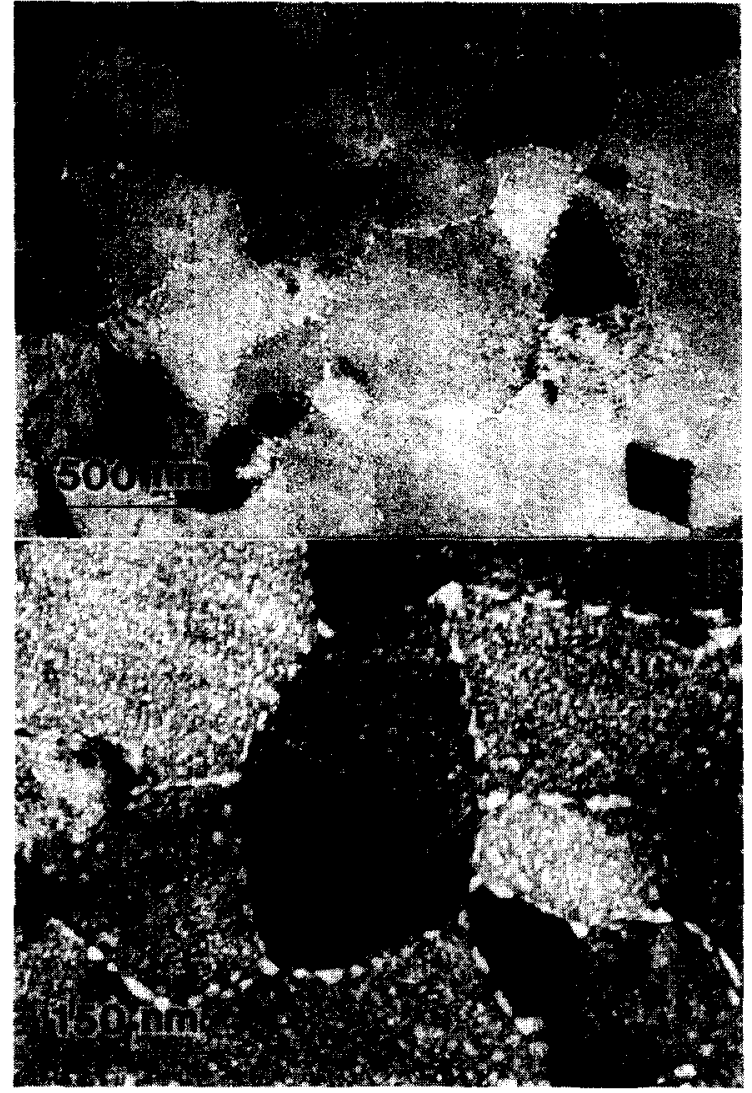

Fig. 10. Planar TEM microstructure of $\mathrm{Ta}_{2} \mathrm{O}_{5}$ films formed on $\mathrm{Si}$ substrates by $\mathrm{Ar}-\mathrm{O}_{2}$ sputtering and annealed at $1000^{\circ} \mathrm{C}$; (b) is a blow-up of (a).

have also observed similar features in $\mathrm{Ta}_{2} \mathrm{O}_{5}$ films formed by high temperature thermal oxidation of $\mathrm{Ta}$ films [34]. Fig. 11 shows a $\mathrm{Ta}_{2} \mathrm{O}_{5}$ film formed by thermally oxidizing an electron-gun-evaporated $\mathrm{Ta}$ film at $1000^{\circ} \mathrm{C}$ for $1 \mathrm{~h}$ in dry oxygen ambient. The substrate of this sample is a 3 in $\mathrm{Si}<100>$ wafer and the Ta thickness is $30 \mathrm{~nm}$. The oxidation in this case is long enough to convert $\mathrm{Ta}$ completely to $\mathrm{Ta}_{2} \mathrm{O}_{5}$. The resemblance of the pore-like features in Fig. 11 to those in Fig. 10 is striking and their amorphous nature is also confirmed by HRTEM examinations. Additionally, we have found, consistently with others $[20,21]$, that the $\mathrm{Ta}_{2} \mathrm{O}_{5}$ film grown by thermal oxidation of $\mathrm{Ta}$ film is entirely amorphous if oxidized below $600{ }^{\circ} \mathrm{C}$, but crystalline $\mathrm{Ta}_{2} \mathrm{O}_{5}$ film is formed at high oxidation temperatures. Like reactively sputtered $\mathrm{Ta}_{2} \mathrm{O}_{5}$ films, the amorphous particles are present in all crystalline $\mathrm{Ta}_{2} \mathrm{O}_{5}$ films formed by thermal oxidation in our observations. In the past, the pore-like features were identified as voids by their appearance in TEM. (The amorphous nature makes the particles featureless and they appear much whiter than the surrounding crystalline $\mathrm{Ta}_{2} \mathrm{O}_{5}$ when viewed in TEM, so it is very easy to have mistaken them as voids.) Under this incorrect presumption

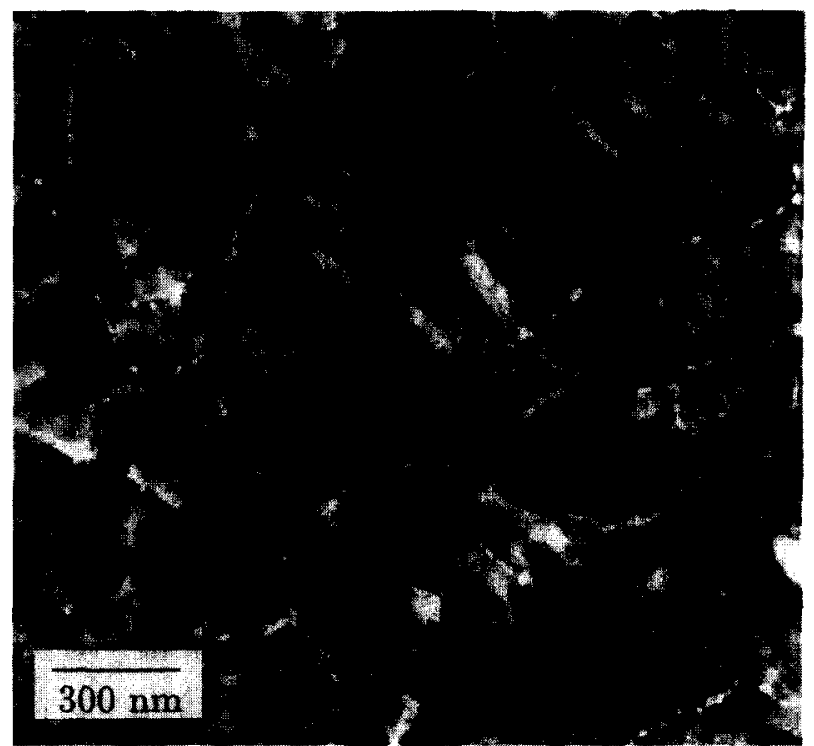

Fig. 11. Planar TEM microstructure of $\mathrm{Ta}_{2} \mathrm{O}_{5}$ film formed on an $\mathrm{Si}$ substrate by thermal oxidation of Ta metal film at $1000^{\circ} \mathrm{C}$ for $1 \mathrm{~h}$ in a dry oxygen ambient.

several hypotheses have been advanced to explain their origin. These include: (1) they are preciptates of Ar gas trapped in the films from the sputtering gas [23], (2) they are voids formed due to inhomeogeneity in stress distribution during the densification of the sputtered films upon annealing [24], or (3) they are voids formed by vacancy condensation [24].

Our HRTEM results, however, cast serious doubt on these hypotheses. Further supporting evidence of these features being amorphous rather than pores is the fact that $\mathrm{Ta}_{2} \mathrm{O}_{5}$ films annealed at $1000^{\circ} \mathrm{C}$ contain large amounts of them (for instance, the apparent volume fraction of amorphous particles in Fig. 7(d) is over $50 \%$ ) yet the film integrity is not impaired at all which is very unlikely if they were voids.

The RBS results presented earlier show clearly that the reactively sputtered $\mathrm{Ta}_{2} \mathrm{O}_{5}$ films contain only $\mathrm{Ta}$ and $O$ (and $\mathrm{Ar}$ if $\mathrm{Ar}$ gas is used in the sputtering). Since $\mathrm{Si}$ is not detected in the $\mathrm{Ta}_{2} \mathrm{O}_{5}$ films, the possibility of the amorphous particles being $\mathrm{SiO}_{2}$ formed by the interaction of the in-diffusing oxygen atoms and the out-diffusig $\mathrm{Si}$ atoms is ruled out. The facts that amorphous particles are observed in $\mathrm{Ta}_{2} \mathrm{O}_{5}$ films formed by pure $\mathrm{O}_{2}$ sputtering and by thermal oxidation of Ta metal films in dry oxygen indicate that their origin is not related to the trapped Ar gas for Ar is not present in these films at all. However, Ar may affect the formation of the amorphous particles in an indirect way bccause films containing Ar seem to have fewer amorphous particles relative to films not containing $\mathrm{Ar}$ (comparing Fig. 4(d) with Fig. 5(d) and Fig. 6(d) with Fig. 7(d)). The fact that no elements other than $\mathrm{Ta}, \mathrm{O}$ and $\mathrm{Ar}$ are detected by RBS strongly suggests that the 
amorphous particles are the remnants of the original amorphous film not being crystallized during the high temperature heat treatment. Evidence supporting this hypothesis is presented in Fig. 12(a) which shows a planar TEM microstructure observed in a partially transformed sample annealed at $800^{\circ} \mathrm{C}$ in the $\mathrm{C}$ series (its corresponding cross-sectional TEM microstructure has been shown in Fig. 6(c)). The area marked $\mathrm{A}$ in this figure is a large untransformed amorphous region surrounded by crystalline $\mathrm{Ta}_{2} \mathrm{O}_{5}$ grains. Fig. $12(\mathrm{~b})$ is a close-up of the interface area between region $A$ (upper right) and a crystalline $\mathrm{Ta}_{2} \mathrm{O}_{5}$ grain (lower left). Numerous tiny amorphous particles can be seen in the crystalline region in Fig. 12(b). From Figs. 4-7 it is evident that the size of the amorphous particles tends to increase with increasing annealing temperature (a similar trend is also observed in thermally oxidized $\mathrm{Ta}_{2} \mathrm{O}_{5}$ films [34]). This tendency is unlikely to be caused by the thermally activated dissolution and growth (Ostwald ripening) process frequently observed in solid state precipitation [35], for there is no driving force for an amorphous $\mathrm{Ta}_{2} \mathrm{O}_{5}$ particle to be dissolved into a crystaline $\mathrm{Ta}_{2} \mathrm{O}_{5}$ and subsequently to precipitate out onto

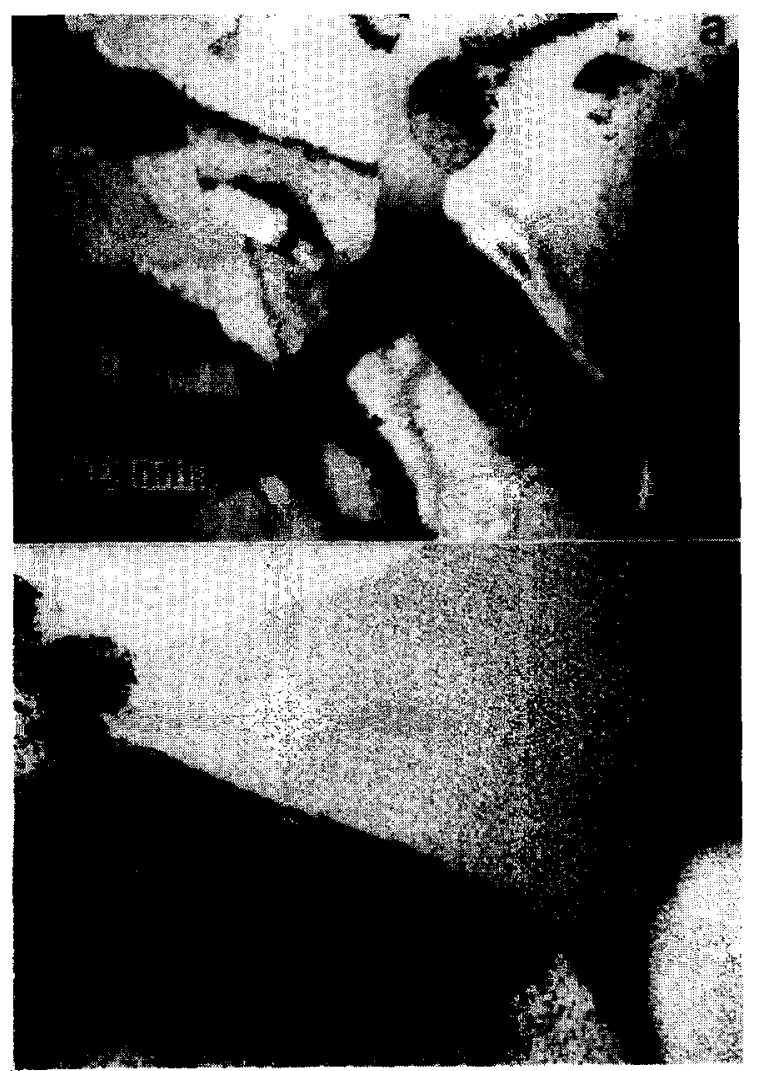

Fig. 12. Planar TEM microstructure of partially crystallized $\mathrm{Ta}_{2} \mathrm{O}_{5}$ film. The letter $A$ denotes an amorphous region surrounded by crystallized oxide. The film was deposited on an $\mathrm{Si}$ substrate by Ar $-\mathrm{O}_{2}$ sputtering and annealed at $800^{\circ} \mathrm{C}$. other amorphous particles. The size difference of the particles at different temperatures may be due to the variation in the rate of crystallization. The faster crystallization associated with the higher temperatures seems to leave larger untransformed regions behind. The residual amorphous particles in otherwise crystalized films are very stable; we have previously shown that a 30 min oxidation treatment at $1050{ }^{\circ} \mathrm{C}$ does not crystallize them [22].

It is well known that $\mathrm{Ta}_{2} \mathrm{O}_{5}$ films formed by reactive sputtering of a $\mathrm{Ta}$ target possess excellent electrical properties if they are amorphous. The electrical properties deteriorate dramatically after a high temperature anneal when the films are crystallized [22]. The amorphous particles have been blamed for the poor dielectric properties of the crystalline $\mathrm{Ta}_{2} \mathrm{O}_{5}$ films based on the incorrect identification of their being voids. Our HRTEM results cast serious doubt on this conjecture and further studies are required to clarify the cause of the large leakage current observed in the crystalline films containing amorphous particles.

\section{Conclusions}

(1) Reactively sputtered $\mathrm{Ta}_{2} \mathrm{O}_{5}$ films adhere very poorly on an $\mathrm{Si}$ substrate. The adhesion improves dramatically on a thermally oxidized Si surface. Films formed by pure $\mathrm{O}_{2}$ sputtering have poorer quality than films formed by $\mathrm{Ar}-\mathrm{O}$, sputtering.

(2) Oxygen in the sputtering gas is found to diffuse through $\mathrm{Ta}_{2} \mathrm{O}_{5}$ and react with the substrate $\mathrm{Si}$ to form an $\mathrm{SiO}_{2}$ layer at the film-substrate interface. The thickness of the interface $\mathrm{SiO}_{2}$ layer increases with increasing oxygen content in the sputtering gas. The interfacial $\mathrm{SiO}_{2}$ layer is formed during sputtering. Subsequent annealing at high temperatures in an Ar ambient has no effect on its thickness.

(3) $\mathrm{Ta}_{2} \mathrm{O}_{5}$ films formed by $\mathrm{Ar}-\mathrm{O}_{2}$ sputtering contains about 2 at.\% Ar which remains in the film even after $1000^{\circ} \mathrm{C}$ annealing.

(4) Reactively sputtered $\mathrm{Ta}_{2} \mathrm{O}_{5}$ films are non-stoichiometric. The $\mathrm{O} / \mathrm{Ta}$ ratio is generally greater than 2.5 but decreases with increasing annealing temperature. This variation in stoichiometry is also reflected by a small decrease in lattice constants with increasing annealing temperature.

(5) The as-deposited $\mathrm{Ta}_{2} \mathrm{O}_{5}$ film is amorphous and remains so if annealed at temperatures below $600{ }^{\circ} \mathrm{C}$. I Iigher temperature anncaling transforms the film to crystalline phase with a concomitant deterioration of electrical properties.

(6) Crystalline $\mathrm{Ta}_{2} \mathrm{O}_{5}$ films contain numerous amporphous particles which have been previously incorrectly identified as voids. The particles have a bimodal size distribution and their average size increases with 
increasing annealing temperature. They are very likely the remnants of the uncrystallized amorphous $\mathrm{Ta}_{2} \mathrm{O}_{5}$ materials.

\section{Acknowledgements}

This work is partially supported by the National Science Council, Taiwan, through Grant NSC 80-0404E-009-02. We appreciate Dr. J. Keenan for the RBS analysis and Dr. W.C. Chen and F.C. Wu for assistance in the TEM.

\section{References}

[1] P. Kofstad, J. Electrochem. Soc. 109 (1962) 579

[2] A.G. Revesz, J.F. Allison and J.H. Reynolds, Comsat. Tech. Rev., 6 (1976) 57.

[3] H. Terui and M. Kobayashi, Appl. Phys. Lett., 32 (1978) 666.

[4] G.M. Choi, H.L. Tuller and J.S. Haggerty, J. Electrochem. Soc., 136 (1989) 835.

[5] A.J. Moulson and J.M. Herbert, Electroceramics; Materials, Properties, Applications, Chapman and Hall, London, p. 197.

[6] K. Ohta, K. Yamada, K. Shimizu and Y. Tarui, IEEE Trans. Electron Dev., 29 (1982) 368.

[7] H. Shinriki, T. Kisu, S. Kimura, Y. Nishioka, Y. Kawamoto and K. Mukai, IEEE Trans. Electron Dev., 37 (1990) 1939.

[8] C.A. Steidel and D. Gerstenberg, J. Appl. Phys., 40 (1969) 3828.

[9] G. Oehrlein, Thin Solid Films, 156 (1988) 207.

[10] T. Kato and T. Ito, J. Eelctrochem. Soc., 135 (1988) 2586.

[11] M. Matsui, S. Oka, K. Yamagishi, K. Kuroiwa and Y. Tarui, Jpn. J. Appl. Phys., 27 (1988) 506.

[12] H. Shinriki and M. Nakata, IEEE Trans. Electron Dev., 38 (1991) 455 .

[13] E. Kaplan, M. Balog and D. Frohman-Bentchkowsky, J. Electrochem. Soc., 129 (1976) 1570.
[14] S. Byeon and Y. Tzeng, Tech. Dig., 1988 IEEE IEDM, IEEE, New York, p. 722.

[15] K. Sunohara and H. Morita, Jpn. J. Appl. Phys., 30 (1991) 3729.

[16] T. Kallfass and E. Lueder, Thin Solid Films, 61 (1979) 259.

[17] S. Seki, T. Unagami and O. Koguye, J. Electrochem. Soc., 132 (1985) 3054

[18] S. Seki, T. Unagami, O. Kogure and B. Tsujiyama, J. Vac. Sci. Technol. A, 5 (1987) 1771 .

[19] U. Teravaninthorn, Y. Miyahara and T. Moriizumi, Jpn. J. Appl. Phys., 26 (1987) 347.

[20] G.S. Oehrlein, F.M. d'Heurle and A. Reisman, J. Appl. Phys., 55 (1984) 3715.

[21] T. Kato and T. Ito, J. Electrochem. Soc., I35 (1988) 2586.

[22] B.-W. Shen, I.-C. Chen, S. Banerjee, G. Brown, J. Bohnman, P.-H. Chang and R. Doering, Tech, Dig., 1988 IEEE IEDM, IEEE, New York, p. 582.

[23] S. Roberts, J. Ryan and L. Nesbit, J. Electrochem. Soc., 133 (1986) 1405.

[24] S.-I. Kimura, Y. Nishioka, A. Shintani and K. Mukai, J. Electrochem. Soc., 130 (1983) 2414.

[25] W.D. Westwood, N. Waterhouse and P.S. Wilcox, Tantalum Thin Films, Academic Press, London, 1975.

[26] D.A. Vermilyea, J. Electrochem. Soc., 104 (1957) 542.

[27] N.F. Jackson, J. Appl. Electrochem., 3 (1973) 91.

[28] R.E. Pawel and J.J. Campbell, J. Electrochem. Soc., 111 (1964) 1230.

[29] S. Tanimoto, M. Matsui, K. Kuroiwa and T. Tarui, J. Electrochem. Soc., 139 (1992) 320.

[30] C.C. Wang, K. Zaininger and M.T. Duffy, RCA Rev., 31 (1970) 728.

[31] W.H. Knausenberger and R.N. Tauber, J. Electrochem. Soc., I20 (1973) 927.

[32] P.-H. Chang, H.-Y. Liu, J.A. Keenan, J.M. Anthony and J.G. Bohlman, J. Appl. Phys., 62 (1987) 2485.

[33] Powder Diffraction File 25-922, International Center for Diffraction Data, Swarthmore, PA, 1993.

[34] F.J. Wu, MS Thesis, National Chiao Tung University, Hsinchu, 1992.

[35] H. Gleiter, in R.W. Cahn and P. Hassen (eds.), Physical Metallurgy, 3rd edn., Elsevier, Amsterdam, 1983, p. 684. 